The University of Southern Mississippi

The Aquila Digital Community

Faculty Publications

4-1-1994

\title{
England and the German Hanse, 1157-1611: A Study of Their Trade and Commercial Diplomacy
}

Richard H. Bowers

University of Southern Mississippi

Follow this and additional works at: https://aquila.usm.edu/fac_pubs

Part of the History Commons

\section{Recommended Citation}

Bowers, R. H. (1994). England and the German Hanse, 1157-1611: A Study of Their Trade and Commercial Diplomacy. Speculum: A Journal of Medieval Studies, 69(2), 524-526.

Available at: https://aquila.usm.edu/fac_pubs/6547

This Book Review is brought to you for free and open access by The Aquila Digital Community. It has been accepted for inclusion in Faculty Publications by an authorized administrator of The Aquila Digital Community. For more information, please contact Joshua.Cromwell@usm.edu. 
as memory aids. They also suggest that the teaching would have been done by the notaries of the tax administration at Constantinople, similar to the teaching of law by the nomikoi, and possibly also in the other great cities of the empire. Perhaps most important they estimate that fiscal "geometric" methods provided reasonable approximations for "compact" ("remassées") parcels, which were most common, but were less accurate for more diffuse ones. A comparison of these theoretical approaches to specific results preserved in documents suggests that the evaluations were satisfactory, within 10-15 percent, in the vast majority of cases. They conclude: "les géométries du fisc byzantin ont rempli leur objet."

This is an excellent edition and an insightful and important study of texts which, while technical in nature, obviously have ramifications of far wider significance.

Denis F. Sullivan, University of Maryland, College Park

T. H. Lloyd, England and the German Hanse, 1157-1611: A Study of Their Trade and Commercial Diplomacy. Cambridge, Eng.: Cambridge University Press, 1991. Pp. ix, $401 ; 19$ tables. $\$ 79.95$.

T. H. Lloyd's England and the German Hanse is the latest of his three published studies relating to the economic history of medieval England. The two earlier works are entitled The English Wool Trade in the Middle Ages (1977) and Alien Merchants in England in the High Middle Ages (1983). His latest study, devoted to the five-century relationship between England and the Hanse, consists of six chapters arranged in a chronological framework. The body of the work is supported by an introduction and a conclusion. The introduction gives the reader a brief overview of the rise of the Hanse, its metamorphosis from an association of German merchants into a commercial confederation of German towns, its decline in the fifteenth and sixteenth centuries, and disappearance in the seventeenth. In chapter 1, which Lloyd has entitled "The Winning of the Hanse Franchises, 11571361," he describes the development of the Anglo-Hanse commercial relationship and explains the privileged status the Hansards acquired in England. The privileges of the Hansards, which included exemptions from some customs levies, ultimately gave the Germans advantages not only over other alien merchants trading in England but even over English merchants themselves. Merchants of the Hanse imported into England herring, furs, linen cloth, bow staves, grain, wax, and naval stores and exported principally first wool and later cloth. Their acceptance in England and the privileged position they won there can be explained in part by the fact that most of the goods they brought to England were necessary-necessary even to the government, which had ships to build and maintain and soldiers to arm and feed. Moreover, England's balance of trade with the Hanse was always favorable so the Germans were long seen as contributing to the wealth of the country and not draining it away like the Italians.

The long honeymoon in the relationship of England and the Hanse ended in the latter half of the fourteenth century, when English merchants began to challenge the Hansards in their own backyard-the Baltic. In the next three chapters of his study Lloyd relates the story of the Hanse's tenacious struggle to protect its privileges and trade in England while at the same time resisting English commercial expansion in the Baltic. Eastern Europe was one of the better markets for English cloth, and English merchants, especially those from the port towns of northeastern England, ventured into the eastern Baltic hoping to gain direct access to this market through Prussia. It was only natural that English merchants who desired to trade in the Baltic expected to enjoy the same privileges in the German cities of the Hanse that Hanse merchants enjoyed in England. Reasonable though their expectations might appear from our vantage point, the Hanse, in three 
centuries of negotiations with England, could never bring itself to accept the principle of reciprocity, even when to have done so would have been in its own best interest. While the English government always demanded reciprocity for its merchants, it was never willing to risk a permanent break with the Hanse as long as it was convinced that there were fiscal or political advantages in maintaining the relationship. Thus the intransigence of Danzig, the principal commercial city in Prussia, and the rest of the Hanse, combined with the perennial hostility of Denmark, which controlled access to the Baltic, effectively checked English ambitions in the eastern Baltic until after 1500.

If the attempt by English merchants to establish themselves in the eastern Baltic ended the honeymoon between England and the Hanse, then Lloyd believes the rise of the association of English cloth-exporting merchants, known as the Merchant Adventurers, in the fifteenth century forebode divorce for the centuries-old commercial marriage. While eastern Europe was one of the better markets for English cloth, the Low Countries had always been the best. Until the French recaptured Calais in 1558 the Merchant Adventurers had shipped their entire cloth export to Calais, where it was offered for sale to buyers from the Low Countries and central and southern Germany. After the loss of Calais the Merchant Adventurers moved their staple to Antwerp, a city where merchants of the Hanse were already well established. In Antwerp the rivalry between the two groups, which had been increasing since the beginning of the century, gave way to recriminations and open hostility, at least on the part of the Merchant Adventurers. The English cloth brought to Antwerp by both the Adventurers and Hanse merchants soon saturated the market and caused prices and profits to plummet. Naturally the Merchant Adventurers blamed the Hanse for the situation and urged the government of Elizabeth I to nullify the privileges of the Hanse, which the government ultimately did and more. Although its privileges had been threatened or suspended many times before, the Hanse had always been able to save them by threatening or actually imposing countersanctions and then by negotiating. This time neither sanctions nor negotiations persuaded the English government to relent.

While the Merchant Adventurers bested the Hanse competitors in Antwerp with the considerable assistance of their government, they had little time to enjoy their victory. Deteriorating English relations with the Low Countries and their ruler, Philip II of Spain, led the government at Brussels to ban the import of English wool and cloth in 1563, forcing the Merchant Adventurers to abandon their Antwerp staple. Over the following decades the Adventurers tried both the cities of Emden and Middleburg as alternative sites to Antwerp, but neither proved a satisfactory location for their staple. They finally established themselves on the Elbe estuary, first in the Hanse city of Hamburg, then at Stade on the west bank of the Elbe, and finally, in 1611, back in Hamburg.

The "Conclusion" is, for the most part, an excellent recapitulation of all the significant events, situations, and conflicts discussed in the previous 362 pages. Member cities of the Hanse from time to time acted independently and counter to the interests of the Hanse as a whole, either to protect their own trade with England or to protect their trading interests elsewhere from English competition. But did these conflicts of selfinterest within the Hanse weaken it, or did the weakness of the Hanse cause its members to act independently? Lloyd concludes, "No certain answer can be given." Hanse resistance and Danish hostility restrained English ambitions in the Baltic until after 1500 and the formation of the Eastland Company, when English merchants finally won their long-sought privileged position in the eastern Baltic. Finally, after besting their Hanse competitors in Antwerp and then losing their staple there, the Merchant Adventurers successfully courted Hamburg and Stade and established themselves in the estuary of the Elbe, where they remained long after the Hanse had faded away.

The emphasis of this study, as the title indicates, is on the Anglo-Hanse commercial 
relationship, the diplomacy undertaken to preserve that relationship, and the trade between England and the Hanse. As usual Lloyd's research has been thorough. The work is firmly grounded on documentary sources, and pertinent existing scholarship is woven into the fabric of the narrative. Deciding whether to organize a study topically or chronologically is always difficult. Lloyd resolved the problem in this instance by employing both systems. Rivalry and changing political and economic circumstances from time to time overwhelmed the Hanse's desire to maintain the status quo in its relationship with England, and there were inevitable and permanent changes. The author discerns six distinct periods in the life of this relationship-hence the division of the study into six chapters, each encapsulated in a time period but each with its own theme, such as "The English Challenge, 1361-1399" or "Rivalry at Antwerp, 1474-1551." Within most of the chapters Lloyd replicates the experiment in historical "horticulture" that he first introduces in chapter 2-the grafting of quantified trade figures to a stock of diplomatic history. After discussing the problems and diplomacy of the period, he begins a thorough, but too often tedious, analysis and explanation of the export and import figures taken principally from the English Customs Accounts that are quantified in the numerous (nineteen) tables interspersed through the study. Problems other than tedium that adversely affect the readability and comprehension of this work include the failure of the author to define terms, identify people and places, and provide the reader with maps. Dozens of terms like "cloth of assise" and "kersey" appear again and again but are never defined. Places and things such as "Blackwell Hall" and the "Bay Fleet" are mentioned but never identified. This fault is so general that when readers find a typographical error such as "city stakes" (p. 364, line 36) for "city-states," they are likely to reach for a dictionary, thinking they have yet again run upon another unfamiliar and undefined term. If one is not certain of the meaning of the adjective "set-piece," as in "set-piece conference" (p. 194, line 4), one may have to consult several dictionaries before obtaining enlightenment. There is, furthermore, at least one sentence in the book (p. 326, lines 13-15) that makes no sense with or without the aid of a dictionary. The absence of maps in a study where geographic entities appear on every page and geographic relationships are utilized in explanations and arguments is simply inexcusable.

On the other hand, the extensive inclusion of German scholarship and the objectivity with which the author has used it are commendable. No one can claim that this work is a study of the Anglo-Hanse relationship from the English point of view. Time will probably establish that the greatest contribution of this study is its comprehensive synthesis of nearly three centuries of English trade data. Lloyd has drawn from numbers compiled by A. R. Bridbury (Medieval English Clothmaking: An Economic Survey), Eileen Power and Michael Postan (Studies in English Trade in the Fifteenth Century), and J. D. Gould (The Great Debasement) and has extended (and in some cases emended) them with figures taken from his own work in the English Customs Accounts. For this, generations of economic historians will surely owe him a debt of gratitude.

\section{RICHARD H. Bowers, University of Southern Mississippi}

\section{Michael MaAs, John Lydus and the Roman Past: Antiquarianism and Politics in the Age of Justinian. London and New York: Routledge, 1992. Pp. ix, 207; 1 map. \$45.}

This elegantly produced libellus earned for its áuthor the Routledge Ancient History Prize for 1990, an honor awarded the following year to Hagith Sivan's Ausonius of Bordeaux, between them a tribute to the continuing vitality of late antiquity as a field of study and the impact of its younger practitioners. One notes with detached amusement 